\title{
Reliability of the Report of Electoral Campaigns to the Portuguese Assembly of the Republic (2005 to 2011)
}

\author{
ELLENE CARVALHO \\ Instituto Superior de Contabilidade e Administração de Lisboa \\ Email: ellenemc@hotmail.com \\ PAULA GOMES DOS SANTOS \\ Instituto Superior de Contabilidade e Administração de Lisboa \\ Email: pasantos@iscal.ipl.pt \\ Tel: +351217984500 \\ CARLOS PINHO \\ Universidade Aberta \\ Email: carlos.pinho@uab.pt \\ Tel: +351213916300 \\ VERA PINTO \\ Instituto Superior de Contabilidade e Administração de Lisboa \\ Email: vcpina@iscal.ipl.pt \\ Tel: +351217984500
}

\begin{abstract}
Act no. 19/2003 sets out the legal framework applicable to the portuguese electoral campaigns' accounts, which are audited by the Constitutional Court. The present investigation aims to study if this framework ensures the faithful representation of the reported information. We analysed the electoral campaigns' accounts to the Assembly of the Republic of years 2005, 2009 and 2011. The main conclusion is the lack of reliability of these accounts, with the existence of recurrent infractions common to various parties, being worth to mention the low fines applied in relation to the infraction amounts. It should be noted that the accounts are submitted without being rectified and that the revenues/expenses with infractions are kept in the accounts (also contributing to the amount of the government grant received). Thus, one can conclude that the benefits that political parties may obtain from such infractions will be greater than the cost of any fines, which may limit the scope of the legal framework in question.
\end{abstract}

Keywords: Electoral Campaigns, Accounts, Reliability, Irregularities, Illegalities.

\section{Introduction}

Political parties are of foremost importance in the consolidation of democracies and are expected to be the link (expressed through voting) between citizens and political institutions (Lisi, 2011). Considering this importance, it is essential that citizens are informed about the management of financial resources used by political parties. Some matters, such as the funding of political parties and their electoral campaigns, have gained more prominence because of scandals related to political corruption and influence peddling. 
Peixoto, Baptista and Valente (2009) consider that this is a global phenomenon. According to Vilela (2016, p.1), "political party funding is a form of restrictive political participation, involving small groups of citizens and institutions, and can bring opportunities for corrupt practices." These practices have negative effects on the democratic system, with some of these effects being highlighted by Malem (2003):

- Possibility of the fundamentals of the theory of political representation, which is the foundation of democratic ideals, being called into question;

- The principles of transparency and publicity are affected;

- The quality of democracy is restricted, through the removal from the political agenda of matters that can give rise to financial compensation, which results in the raising of irregular funds by political parties.

In this regard, it is important to develop the best practices in order to prevent and control the corruption associated with political party funding. One way to do so is to regulate party funding in order to guarantee the principle of transparency (Sousa, 2005).

In this context, the present study analyses political party funding in Portugal, in particular the financing of the electoral campaigns and their legal framework. Electoral campaigns in Portugal receive government grants as one of their sources of funding. So, campaign accounts are a critical element to verify the right to receive those grants and to verify the fulfilment of the obligations set forth in the Act on the Financing of Political Parties and Electoral Campaigns, Act no. 19/2003, of June 20, 2003.

Hence it is important to know the legal framework applicable to the financial resources of electoral campaigns and whether political parties comply with that framework when reporting campaign accounts. The responsible for the assessment of the electoral campaigns accounts is the Constitutional Court (TC), which ultimately decides on their regularity and legality. With the present study, we aim to answer the following research question:

Does the portuguese legal framework applicable to electoral campaigns accounts ensure their faithful representation?

This study analyses the accounts from electoral campaigns to the portuguese Assembly of the Republic (AR) in the years where Act no. 19/2003 was applied and for which the examination procedures held by the TC have already been completed: years 2005, 2009 and 2011.

\section{The Act on the Financing of Political Parties and Electoral Campaigns as of 2005}

Act no. 19/2003, of June 20, 2003, sets out the framework for the financing of political parties and electoral campaigns, superseding Act no. 56/98, of August 18, 1998 (amended by Act no. 23/2000, of August 23, 2000, and Organic Act No. 1/2001, of August 14, 2001).

Judgment no. 563/2006 of the Constitutional Court (TC) emphasizes the following innovations introduced by that Act, with repercussions in the examination process of the accounts from electoral campaigns:

- Appointment of the TC as the office responsible for examining the accounts from electoral campaigns (article 23 (1)), replacing the National Electoral Commission;

- Creation of the Political Financing and Accounts Entity (ECFP), acting as technical assistant to the Constitutional Court in the audit process of the accounts of political parties and electoral campaigns, which is responsible for examining cases that the Court evaluates (Article 24 (1) and (2)). 
The supervision system of the accounts of political parties and electoral campaigns was implemented by Organic Act no. 2/2005, of January 10, 2005. This Act set out the procedural process and the needed articulation between the various entities involved in the auditing process. It is worth being mentioned that Act no. 19/2003 and Organic Act no. 2/2005, took effect on January 1, 2005.

\section{Legal framework of Campaign Accounts for the AR}

The rules concerning the funding of electoral campaigns are defined in Chapter III, articles 15 to 22, of Act no. 19/2003, which establish, namely, the rules that electoral campaign expenses and revenues must comply with and their limits. Table 1 presents the main rules on electoral campaign accounts.

Table 1 a. Main rules to be observed in Electoral Campaign Accounts

\section{Article 12 Accounting regime}

Political parties are required to keep organized accounting, making possible to know their financial position and to verify the fulfilment of the obligations set forth in this Act.

Bank statements of the campaign accounts must be presented.

Revenue from fundraising activities must be presented, in the form of a proper list, attached to the campaign accounts, with identification of the type of activity and date of occurrence.

\section{Article 15 Rules and treatment of revenue and expenditure}

The campaign revenues and expenditures shall be recorded in specifically created accounts and shall comply with article 12 .

The electoral campaign accounts correspond to bank accounts specifically opened for this purpose, where the respective revenues are deposited and all expenses related to the campaign are handled.

The campaign budget must be submitted to the Constitutional Court no later than 5 days after publication of the decree stating the date of the elections. These budgets are made available on the official website of the Constitutional Court from the day following their submission.

\section{Article 16 Campaign revenue}

Electoral campaign activities can only be funded by:

a) Government grants;

b) Contribution from political parties that present or support candidacies for the elections to the Assembly of the Republic;

c) Proceeds from fundraising activities for the electoral campaign.

Political parties may make advances to campaign accounts, namely for the settlement of expenses until the receipt of the government grants, which must, as well as the contributions from the parties, be certified by documents issued by the competent organs of the respective party.

Revenue from fundraising activities, even if within the scope of the campaign for that purpose, is subject to the limit of 60 times the value of the social support indexation (IAS) per donor, and must be donated by cheque or by other banking means so that the amount and its origin can be traced. When related to the last day of the campaign, financial resources derived from fundraising activities shall be deposited until the following third business day.

The use of assets owned by the political party, as well as the collaboration of militants, sympathizers and supporters, are not considered as revenues or campaign expenses.

Organic Act no. 2/2005, related to the organisation and operation of the Political Financing and Accounts Entity, sets out, in Article 16, the obligation that electoral campaign actions must be communicated to the Entity, as well as their means when they involve costs higher than one minimum wage. The timeframe for fulfilling this duty ends on the date of submission of the respective accounts. 
Table 1 b. Main rules to be observed in Electoral Campaign Accounts (cont.)

Article 19 Electoral campaign expenses

Only the expenses incurred by the candidates, with electoral intention or benefit, are considered within the six months immediately preceding the date of the respective elections.

They must be itemised per category, by attaching a certification document in relation to each expense.

Payment must be made by bank check or by other banking means that allows identification of the amount and the entity to which the payment is made, except for expenses of less than the value of the ISS provided that, during this period, do not exceed the overall amount of $2 \%$ of the limits set for campaign expenditure.

\section{Article 20 Limit of electoral campaign expenses}

The maximum allowed expenditure limit for each electoral campaign for the Assembly of the Republic is established at 60 times the value of the ISS for each candidate presented during the electoral campaign, and political parties or coalitions must declare to the Constitutional Court the number of candidates presented to each election.

With regard to government grants for electoral campaigns, it is set forth by Articles 17 and 18 of Act no. 19/2003. In accordance with Article 152, Act no. 64-A/2008, of December 31, 2008, the grant is of a total amount equivalent to 20,000 times the value of the social support indexation (IAS). In the original wording, the grant is of a total amount equivalent to 20,000 monthly minimum wages. It is worth noting that according to Article 152 (2) and (3), the applicable changes only take effect in the year in which the IAS amount reaches the value of the monthly minimum wage fixed for the year 2008. Hence, as long as this convergence does not occur, the amounts of public grants, financing of political parties and electoral campaigns and fines remain at 2008 levels. It should be noted that this convergence has not yet occurred.

The public grant provided for in Article 17 of Act no. 19/2003, is aimed to cover the expenses of electoral campaigns and is allocated to parties that, in the case of elections for the Assembly of the Republic, run for, at least, $51 \%$ of offices subject to suffrage and obtain representation. This grant has as a limit attributed to each of the candidacies an amount that cannot, under any circumstance, according to Article 18 (4), Act no. $19 / 2003$ "exceed the value of expenses [...] actually effected, less the amount [...]... from fundraising activities." Thus, the value of the government grant, plus any reimbursed VAT and the proceeds from fundraising activities, shall not, in any case, exceed the total value of expenditure incurred (Judgment no. 346/2012). It is worth mentioning that, in case of any surplus arising from fundraising actions related to expenses incurred, that shall be transferred back to the State. As per Article 27, each candidacy must provide the TC with detailed accounts of its electoral campaign, within a maximum period of 60 days after the full payment of the government grant (this is requested to the President of the AR within 15 days after the official declaration of the election results, and must be paid within 60 days, after which interest will be due at the statutory rate).

\section{Responsibility for Campaign Accounts}

Article 21 of Act no. 19/2003 sets forth that a financial agent shall be appointed for each campaign account, who will be responsible for depositing all revenue and controlling and authorising any expenditure. Within 30 days after the deadline for submitting lists or candidacies for any election, the political party or coalition shall publish, on a national newspaper of widespread circulation ${ }^{1}$, the complete list of financial agents. In accordance with Article 22, financial agents are responsible for the preparation and presentation of the respective campaign accounts. Political parties or coalitions, the first candidates on each list or the first

${ }^{1}$ Wording given by Article 1, Act no. 55/2010, of December 24, 2010. In the original wording, such lists should be published in two newspapers of widespread circulation. 
proponent of each group of citizens who are candidates for any election, as the case may be, shall be jointly and severally liable with the financial agents.

It should be highlighted that although the first candidates on each list are defined as jointly and severally liable, they are not mentioned in Article 28, which sets out sanctions. As Miguéis, Luís, Almeida, Lucas, Rodrigues and Almeida (2015) recognize, candidates, who are part of political party lists, have not been held accountable in political campaigns, as sanctions have been applied only to parties and financial agents. It is important to note that, although they are responsible for the preparation and presentation of campaign accounts, the Act does not demand any specific training from financial agents.

\section{Appraisal and Audit of Campaign Accounts}

As per Article 23 of Act no. 19/2003, the TC shall assess the accounts from electoral campaigns, expressing its opinion on their regularity and legality. The TC is technically assisted in the appraisal and audit of the accounts from electoral campaigns by the Political Financing and Accounts Entity (ECFP), which is responsible for examining the processes judged by the TC, as well as for auditing the correspondence between declared and actual expenses (its organisation and operation is established by Organic Act no. 2/2005, of January 10, 2005, which sets out the obligations of the Entity in Articles 15 to $18)$.

It is worth noting that the TC audits compliance with Act no. 19/2003, but the power to carry out legislative changes lies with the AR. In this respect, Soares $(2012$, p.18) points out that "the regulation of political party financing is also being debated with another problem: independent regulation. The rules governing the financing of political parties are discussed, approved and rejected by those to whom they apply, which may lead to legislation produced in this matter that fails to meet the standards of a demanding political financing control system and the expectations of the democratic system".

The last intervening agent of this audit process is the Public Prosecution Service (MP). After the Judgment of the TC, the latter notifies the MP to promote the enforcement of the respective penalties (fines) against political parties/coalitions and their financial agents.

\section{Sanctions}

Regarding sanctions, it should be highlighted that the TC is the entity competent to enforce the sanctions provided for in Act no. 19/2003, except for criminal sanctions, and the ECFP is the entity competent to enforce the sanctions provided in Organic Act no. 2/2005, of January 10, 2005.

It is important to delimit the types of conducts that can be punished with a fine. As stated in Judgment no. 417/2007, and repeated in Judgments no. 77/2011, 139/2012 and 177/2014, there is no "perfect match between the duties that Chapter III of Act no. 19/2003 imposes on candidacies and the fines set out in Articles 30 to 32. Moreover, there are duties whose breach is not sanctioned with a fine." Thus, there may be facts that constitute situations of noncompliance with specific provisions contained in Chapter III relating to the financing and organisation of electoral accounts (illegalities) that are not subject to sanction. Table 2 shows the conducts that can be penalised with a fine in terms of financing and organisation of electoral campaign accounts, in accordance with Judgment no. 177/2014.

By comparing the next Table with the rules to be observed in the Electoral Campaign Accounts (shown in Table 1), there are several conducts that constitute illegalities, but for which no specific sanctions are foreseen, such as failure to submit bank statements with movements from campaign accounts, or the receipt of revenue and payment of campaign expenses through bank account other than the specifically constituted for this purpose. 
Table 2. Conducts punishable by fine

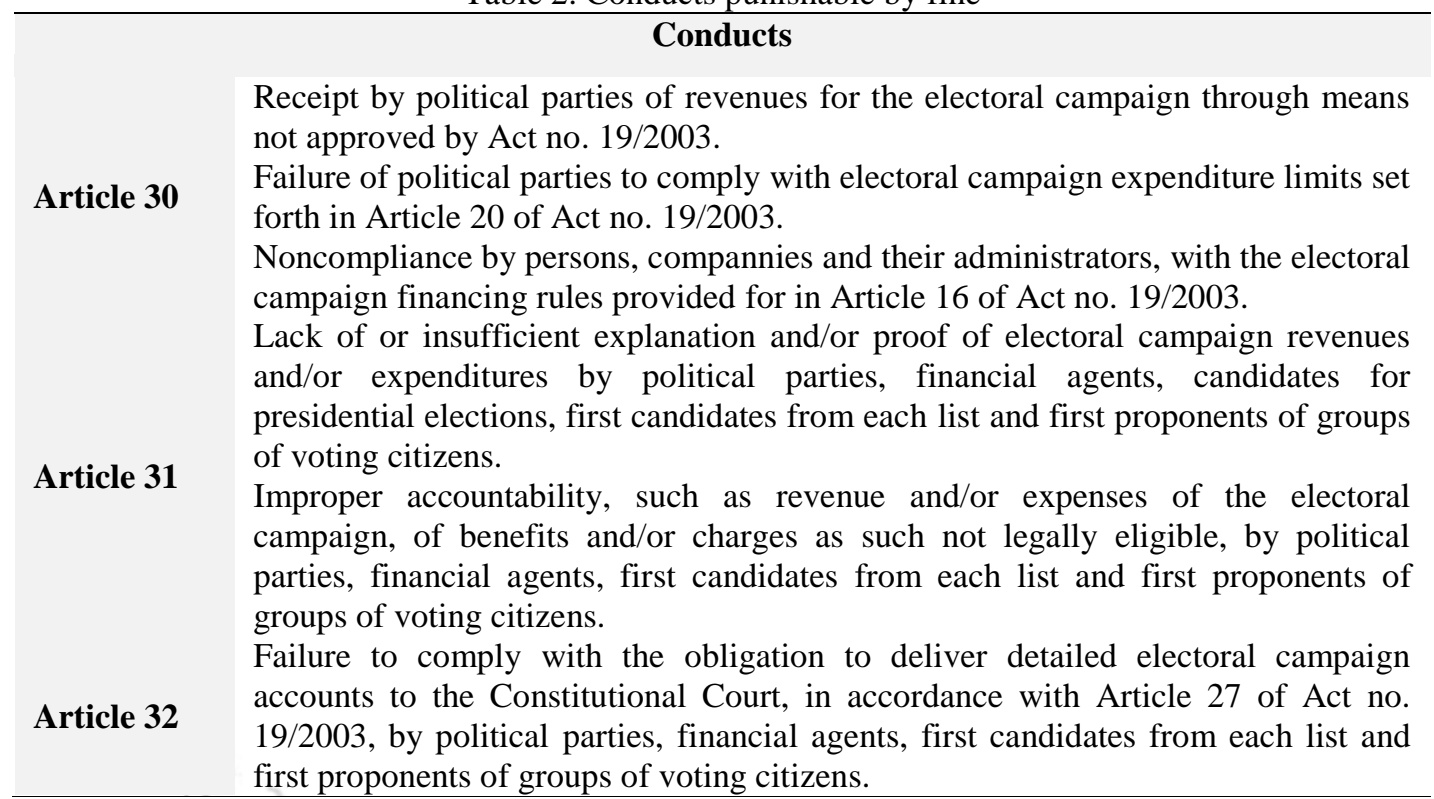

In addition to illegalities, there may be conducts which, while not corresponding to breaches of specific provisions of Chapter III, still constitute weaknesses or inadequacies in the organisation of the accounts, which is likely to call into question the reliability of the accounts and to prevent, for such reason, the knowledge of the financial situation of the candidacies and the verification of compliance with the obligations to which they are legally bound (Judgment no. 177/2014).

These facts constitute irregularities that may undermine the overall duty of accounting organisation set out in Article 12 (1) of Act no. 19/2003 applicable to electoral candidacies under Article 15 (1), of the same Act. As an example of a conduct that constitutes an irregularity, Judgment no. 563/2006 shows the lack of or insufficient internal mechanisms for controlling campaign actions and the recording of their expenses, in order to confirm that such actions and expenses are fully reflected in the accounts and to verify compliance with the obligations established by law.

Therefore, it should be noted that not all illegalities and irregularities detected in electoral campaign accounts imply administrative responsibility. This is because, despite the breach of Act no. 19/2003, with regard to the financing and organisation of electoral campaign accounts, it may result from breach of any of the specific duties imposed by its rules or from breach of the overall duty of accounting organisation, only those conducts that are liable to the provisions of Articles 30 to 32 of that Act are subject to a fine. As per Judgment no. 417/2007, candidacies "cannot be sanctioned by actions or omissions that the law does not declare punishable and cannot be subject to fines that are not expressly set forth in the law".

According to Soares (2012, p.17), political parties have a habit of incurring in a culture of wastefulness and "do not facilitate the process of effective implementation of the political financing regulation, not only because the effort required to do so is not rewarded, but also because often the result of the acts practiced outweighs the moral, ethical and punitive cost that arising thereof".

Table 3 shows the most recurrent misconducts detected in the various TC Judgments relating to electoral campaigns and the respective position of the Court. 
Table 3. Recurrent and common misconducts to several Parties

\section{Contributions from parties classified as advances}

According to Judgment no. 135/2011, "advanced amounts and subsequently returned are not a contribution or advance from the party, whose accounting cannot, under any circumstances, be discontinued."

\section{Contributions from parties after the election}

The Court has stated, since Judgment no. 567/2008 that "the contributions from parties to the financing of the electoral campaign must be transferred during the campaign". However, there may be "acceptable justification for partisan contributions registered after the election" (Judgment no. $316 / 2010)$. ECFP itself states in its Recommendations $(2011$, p. 7$)$ that "if the Campaign does not have its own funds for the settlement of supplier invoices that have not been paid by the day of the elections, the Party shall transfer the funds to the Campaign that allows for the settlement of obligations within said period (of 90 days)." Thus, transfers that occur after the elections will be admissible, provided that they are justified within a period of 90 days.

\section{Understatement of grant proceeds}

Judgment no. 19/2008 (reproduced in Judgment no. 135/2011), establishes that "according to Article 15 of Act no. 19/2003, the accounts from electoral campaigns follow the regime of Article 12 of the same Act, which considers that the principles applicable to the Official Chart of Accounts with due adaptations apply to the accounting system. The Official Chart of Accounts, in turn, with the aim of obtaining a true and proper image of the financial situation and results of operations, establishes as a fundamental accounting principle that of materiality, according to which "financial statements must show all the relevant elements". Thus, the Court considers that, since the accounts must reflect all the relevant elements, there is a overall duty to rectify them, even if the relevant fact occurs at a later time than the submission of those accounts and provided that such rectification can be effected in timely manner, namely before they are judged (Judgment no. 346/2012).

\section{Opening of several bank accounts}

The issue of the opening of several electoral campaign bank accounts was the subject of a ruling by the Court in Judgment no. 617/2011, stating that such an opening constitutes "a breach of the provisions of Article 15 of Act no. 19/2003, because, according to that concept, each campaign account corresponds to a bank account. Indeed, this is the only way to attain the pursuit of paragraph 3 of that Article that requires that revenues shall be deposited and all expenses shall be paid for". Furthermore, a number of bank accounts would be seen as hindering control and facilitating movements that are more difficult to trace (Judgment no. 346/2012).

Expenses billed after the election

As the Court recalled in Judgment no. 567/2008, "one thing is that the expenditure was carried out after the elections, another is that it may have been done before, but has been billed only afterwards (whether for reasons attributed to the supplier, or for any other reason)". As it was also added, "only in the first case there really is an irregularity." Conversely, with regard to the realisation of expenses after the elections, it was written in Judgments no. 563/2006 and 19/2008 that "the inclusion in the campaign accounts of expenses incurred after the elections constitutes an irregular practice, where it is not duly justified."

\section{Lack of request for confirmation of balances to banks and suppliers}

According to the Court, Judgment no. 394/2011, it refers to "cases in which the non-fulfilment of an obligation of the parties is being judged, which may indicate breach of a duty to cooperate with the ECFP imposed by Article 15 of Organic Act no. 2/2005 and, if applicable, ECFP itself, in accordance with Article 47 (2) of the same Act", but without any independent relevance in the context of the campaign by the TC. 


\section{Empirical Study}

\section{Objectives and Methodology}

The objective of this investigation was to study if the portuguese legal framework applicable to electoral campaigns accounts ensures the faithful represention of the reported information. In order to do so, we studied the electoral campaign accounts for the Assembly of the Republic related to years 2005, 2009 and 2011. In the present study, the accounts for the 2015 campaign were not considered because the assessment process by the TC has not yet been completed, nor the accounts from campaigns prior to year 2005 as they are not governed by Act no. 19/2003.

Data for this analysis was collected through the accountability of each political party's campaigns, the ECFP Reports and the respective TC judgments. In the analysis of the campaign accounts, the concept of "infractions" will be used as synonymous with irregularities or illegalities detected by the TC, due to the application of Act no. 19/2003 (it is worth mentioning that the TC does not award decisions on noncompliance with the duties imposed by Organic Act no. 2/2005, as this is the competence of the ECFP). The analysis of electoral campaign accounts will be presented per year (2005, 2009 and 2011), with the option of presenting information by party/coalition. This study is limited to the accounts of the five parties that elected representatives to the AR. In all the years under analysis, the parties that elected representatives were the CDS-PP, PS, PSD, BE and the CDU coalition.

\section{Analysis of the 2005 Accounts}

Regarding the accounts from political party campaigns with representation in the AR as a result of the 2005 elections, a number of situations was observed which raised doubts in the audit. Some of them turned out to be infractions that were sanctioned by the TC. Table 4 shows the amounts of actual expenses and revenues in which these infractions occurred (and their weight in the total amounts).

Table 4. Expenditure and Revenues with infractions in 2005

\begin{tabular}{lcccccc}
\hline $\begin{array}{l}\text { Parties/ } \\
\text { Coalition }\end{array}$ & $\begin{array}{c}\text { Actual } \\
\text { Expenditure }\end{array}$ & \multicolumn{2}{c}{$\begin{array}{c}\text { Expenses with } \\
\text { infractions }\end{array}$} & $\begin{array}{c}\text { Actual } \\
\text { Revenues }\end{array}$ & Revenue with infractions \\
\hline CDS-PP & $2,243,619.20 €$ & $31,625.00 €$ & $1.4 \%$ & $2,186,100.59 €$ & $1,594,947.73 €$ & $73 \%$ \\
PSD & $4,737,821.53 €$ & 0 & 0 & $3,079,709.53 €$ & $169,244.00 €$ & $5.5 \%$ \\
PS & $4,700,000.00 €$ & 0 & 0 & $4,600,000.00 €$ & $828,169.00 €$ & $18 \%$ \\
BE & $561,594.00 €$ & $26,126.00 €$ & $4.7 \%$ & $561,594.00 €$ & $4,160.00 €$ & $0.7 \%$ \\
CDU & $843,629.00 €$ & 0 & 0 & $939,830.00 €$ & $292,218.00 €$ & $31.1 \%$ \\
\hline
\end{tabular}

It can be seen that the infractions observed in 2005 are mainly focused on revenues, especially with CDSPP, where infractions were detected in $73 \%$ of actual revenues. It is worth noting that the CDU has submitted higher revenues than expenditure, which is an anomalous situation since the party received government grants.

Act no. 19/2003 does not explicitly provide for situations in which the revenues and expenses from campaigns have different values. However, these situations may indicate an underestimated revenue. For example, if the party has paid for campaign expenses through the party's bank account, the "Party Contribution" is not recorded in the campaign account and the revenue is underestimated.

The infractions described in Table 5 were those identified by the audit in the first year of Act no. 19/2003. 
Table 5. Main infractions in 2005

\begin{tabular}{lll}
\hline $\begin{array}{c}\text { Parties/ } \\
\text { Coalition }\end{array}$ & \multicolumn{1}{c}{ Infractions } & \multicolumn{1}{c}{ Amounts } \\
\hline CDS-PP & Party contribution unaccounted for. & $1,594,947.73 €$ \\
& Campaign expense unaccounted for. & $31,625.00 €$ \\
PSD & Party contribution unaccounted for. & $111,845.00 €$ \\
& Cash donation without identification of the donor or origin. & $57,399.00 €$ \\
& Payment of campaign expense through party's bank account. & $251,213.00 €$ \\
& Fundraising resources deposited after the election. & $381,000.00 €$ \\
& Fundraising resources with insufficient supporting documentation. & $195,956.00 €$ \\
BE & Fundraising resources deposited after the election. & $4,160.00 €$ \\
& Campaign expense with insufficient supporting documentation. & $26,126.00 €$ \\
& Payment of campaign expense through party's bank account. & $97,920.00 €$ \\
CDU & Fundraising resources deposited in cash without identification of the & $8,931.00 €$ \\
& donor and origin. & \\
& Other cash deposits without identification of the donor and origin. & $6,108.00 €$ \\
& Party contribution unaccounted for. & $179,259.00 €$ \\
\hline
\end{tabular}

For the 2005 campaign, the TC published five judgments, including Judgments no. 417/2007 and no. 405/2009. Table 6 lists all infractions committed by the parties and sanctioned by the TC, the articles that the TC deemed as breached, as well as the amount of the fines that were charged. According to the data analysis, it was found that the infractions identified are common to the various parties, mainly related to the non-recognition and/or non-verification of the revenues and expenses of the campaign, which hinders the transparency of the accounts. It is worth noting that despite the identification of infractions, the respective amounts remain in the campaign accounts.

Table 6. Infraction Values and Fines Applied in 2005

\begin{tabular}{|c|c|c|c|c|c|c|}
\hline & Limits & CDS-PP & PSD & PS & BE & CDU \\
\hline $\begin{array}{l}\text { Infraction } \\
\text { values }\end{array}$ & - & $1,626,572.73 €$ & $169,244.00 €$ & $828,169.00 €$ & $30,286.00 €$ & $292,218.00 €$ \\
\hline $\begin{array}{l}\text { Breached } \\
\text { Articles }\end{array}$ & - & 12 and 15 & 12,15 and 16 & 12 and 15 & 12 and 15 & $\begin{array}{l}12,15 \text { and } \\
16\end{array}$ \\
\hline $\begin{array}{l}\text { Fines per } \\
\text { Parties }\end{array}$ & $\begin{array}{l}3,747.00 € \text { to } \\
74.940,00 €\end{array}$ & $23,231.40 €$ & $25,104.90 €$ & $21,357.90 €$ & $11,241.00 €$ & $15,737.40 €$ \\
\hline $\begin{array}{l}\text { Fines per } \\
\text { Financial } \\
\text { Agents }\end{array}$ & $\begin{array}{l}374.70 € \text { to } \\
29,976.00 €\end{array}$ & $1,600.00 €$ & $1,400.00 €$ & $1,100.00 €$ & $900.00 €$ & $*$ \\
\hline Infractions & - & 7 & 6 & 6 & 5 & 6 \\
\hline
\end{tabular}

*Administrative proceeding ended due to death of the financial agent.

A lack of proportionality between the fines and the amounts of the infractions is observed, and it should be pointed out that the maximum amount of the fine applied to the parties was well below the maximum limit set out by Act no. 19/2003.

It is worth noting that the previous tables only include infractions whose amounts were disclosed in the judgments of the TC because they were sanctioned. However, the 2005 TC judgments list a number of situations identified by the audit, namely on the amounts of revenue collected during the campaign, which were not sanctioned. For example, CDS-PP received more than $90 \%$ of "Fundraising resources" during the campaign, having recognised most of the revenue in the party accounts $(1,265,135 €)$ and not in the campaign (12,500 €). That is, although the party has complied with Act no. 19/2003 of June 20, 2003, this 
is an example of a hypothetical underestimation of the revenues of the campaign identified by the audit that was not condemned by the TC.

In the audit reports, a number of situations are identified in which auditors declare themselves unable to carry out their audit to produce a secure opinion on the accounts. It should be noted that the very shortcomings of the legislation result in limitations on the audit. For instance, if the party does not confirm the balance of transactions with suppliers, the audit cannot impose its obligation since it is not provided for in Act no. 19/2003.

\section{Analysis of the 2009 Accounts}

In the 2009 campaign, situations involving infractions, both in terms of expenditure and revenue were detected by the TC audit. However, revenues continue to represent the highest value of incidents. The BE accounts were the only ones in which no infractions were identified, as can be seen in Table 7 .

Table 7. Expenses and Revenues with Infractions in 2009

\begin{tabular}{ccccccc}
\hline $\begin{array}{c}\text { Parties/ } \\
\text { Coalition }\end{array}$ & $\begin{array}{c}\text { Actual } \\
\text { Expenditure }\end{array}$ & \multicolumn{2}{c}{$\begin{array}{c}\text { Expenses with } \\
\text { infractions }\end{array}$} & \multicolumn{2}{c}{$\begin{array}{c}\text { Actual } \\
\text { Revenues }\end{array}$} & \multicolumn{2}{c}{$\begin{array}{c}\text { Revenue with } \\
\text { infractions }\end{array}$} \\
\hline CDS-PP & $1,020,339.33 €$ & $195,402.04 €$ & $19.2 \%$ & $915,097.83 €$ & $755,000.00 €$ & $82.5 \%$ \\
PSD & $2,918,664.92 €$ & 0 & 0 & $2,918,664.92 €$ & $2,526,074.91 €$ & $86.6 \%$ \\
PS & $5,467,056.11 €$ & $5,794.60 €$ & $0.1 \%$ & $5,530,651.33 €$ & $254,638.60 €$ & $4.6 \%$ \\
BE & $1,185,640.90 €$ & 0 & 0 & $1,640,375.00 €$ & 0 & 0 \\
CDU & $1,225,754.79 €$ & $443,259.77 €$ & $36.2 \%$ & $1,225,754.79 €$ & $963,441.65 €$ & $78.6 \%$ \\
\hline
\end{tabular}

The infractions related to the item "Party Contribution" is the one that has the greatest number of incidents, according to the information in the ECFP reports, and stems from the fact that the parties make payments of campaign expenses through their bank accounts. Table 8 lists infractions disclosed by TC judgments.

Table 8. Main infractions in 2009

\begin{tabular}{lll}
\hline $\begin{array}{c}\text { Parties/ } \\
\text { Coalition }\end{array}$ & \multicolumn{1}{c}{ Infractions } & \multicolumn{1}{c}{ Amounts } \\
\hline \multirow{4}{*}{ CDS-PP } & Party Contribution unaccounted for. & $750,000.00 €$ \\
& Underestimated grant revenue. & $5,000.00 €$ \\
& Expenses with insufficient supporting documentation for justification. & $80,567.20 €$ \\
& Overestimated expenditure. & $649.00 €$ \\
& Non-VAT accountability. & $114,185.84 €$ \\
PSD & Party Contribution unaccounted for. & $2,343,262.30 €$ \\
& Underestimated grant revenue. & $182,812.61 €$ \\
PS & Underestimated grant revenue. & $229,638.60 €$ \\
& Expenses with insufficient supporting documentation for justification. & $5,794.60 €$ \\
BE & Fundraising resources after election. & $25,000.00 €$ \\
& & - \\
& Party Contribution unaccounted for. & $890,820.23 €$ \\
CDU & Underestimated grant revenue. & $49,336.13 €$ \\
& Expenses with insufficient supporting documentation. & $443,259.77 €$ \\
& Fundraising resources with insufficient supporting documentation. & $18,285.29 €$ \\
& Contribution from Legal Entities. & $5,000.00 €$ \\
\hline
\end{tabular}

Table 9 shows the amounts of the applied fines and the amounts of the infractions identified. The data was collected from Judgments no. 346/2012 and no. 177/2014. 
It should be noted that the highest fine imposed on parties corresponds to about one-tenth of the maximum limit set forth by Act no. 19/2003. It is also worth mentioning that the infraction amounts did not result in an increase in fines, as it can be seen in the case of the PSD.

Table 9. Infraction Values and Fines Applied in 2009

\begin{tabular}{ccccccc}
\hline & Limits & CDS-PP & PSD & PS & BE & CDU \\
\hline $\begin{array}{c}\text { Infraction } \\
\text { values } \\
\text { Breached } \\
\text { Articles }\end{array}$ & - & $950,402.04 €$ & $2,526,074.91 €$ & $260,433.20 €$ & - & $1,406,701.42 €$ \\
$\begin{array}{c}\text { Fines per } \\
\text { Parties }\end{array}$ & $\begin{array}{c}4,260 € \\
\text { to }\end{array}$ & $\begin{array}{c}12,15 \text { and } \\
19\end{array}$ & 12 and 15 & 12,15 and 19 & - & $8,12,15,16$ \\
and 19 & \\
& $85,200 €$ & & & & & \\
Fines per & $426 €$ to & $900.00 €$ & $5,500.00 €$ & $6,500.00 €$ & - & $8,500.00 €$ \\
$\begin{array}{c}\text { Financial } \\
\text { Agents }\end{array}$ & $34,080 €$ & $550.00 €$ & $650.00 €$ & - & $950.00 €$ \\
Infractions & - & 6 & & & & \\
\hline
\end{tabular}

\section{Analysis of the 2011 Accounts}

In 2011, the infractions assigned to the parties refer essentially to campaign expenditures, as it can be seen in Table 10. It should be noted that the BE remained the only party not to submit amounts with infractions.

Table 10. Expenses and Receipts with Infractions in 2011

\begin{tabular}{cccccccc}
\hline $\begin{array}{c}\text { Parties/ } \\
\text { Coalition }\end{array}$ & $\begin{array}{c}\text { Actual } \\
\text { Expenditure }\end{array}$ & \multicolumn{2}{c}{$\begin{array}{c}\text { Expenses with } \\
\text { infractions }\end{array}$} & Actual Revenues & \multicolumn{2}{c}{$\begin{array}{c}\text { Revenue with } \\
\text { infractions }\end{array}$} \\
\hline CDS-PP & $796,714.75 €$ & $17,343.28 €$ & $2.2 \%$ & $796,714.75 €$ & 0 & 0 \\
PSD & $3,828,382.29 €$ & $42,957.75 €$ & $1.1 \%$ & $3,828,382.29 €$ & $160.00 €$ & $0.004 \%$ \\
PS & $4,132,885.35 €$ & $1,193,366.46 €$ & $28.9 \%$ & $4,133,205.44 €$ & 0 & 0 \\
BE & $772,558.29 €$ & 0 & 0 & $772,558.29 €$ & 0 & 0 \\
CDU & $924,887.16 €$ & $171,150.69 €$ & $18.5 \%$ & $924,887.16 €$ & 0 & 0 \\
\hline
\end{tabular}

It is worth looking more closely at some of the facts that gave rise to the infractions identified. Table 11 lists only the infractions whose amounts were disclosed in the judgments and were subject to sanction.

Table 11. Main infractions in 2011

\begin{tabular}{lll}
\hline $\begin{array}{c}\text { Parties/ } \\
\text { Coalition }\end{array}$ & \multicolumn{1}{c}{ Infractions } & \multicolumn{1}{c}{ Amounts } \\
\hline \multirow{2}{*}{ CDS-PP } & Expenses with insufficient supporting documentation. & $6,161.08 €$ \\
& Expenses with insufficient supporting documentation for justification. & $11,182.20 €$ \\
PSD & Expenses with insufficient supporting documentation for eligibility. & $42,957.75 €$ \\
& Fundraising resources deposited after the election. & $160.00 €$ \\
& Expenses with insufficient supporting documentation. & $25,390.77 €$ \\
& Expenses with insufficient supporting documentation for justification. & $91,782.46 €$ \\
& Expenses with insufficient supporting documentation for justification. & $1,058,416.23 €$ \\
& Underestimation of campaign expenditure. & $17,777.00 €$ \\
BE & \multicolumn{1}{c}{-} & - \\
CDU & Expenses with insufficient supporting documentation for eligibility. & $97,365.00 €$ \\
& Expense paid through the party's bank account (not Campaign). & $73,785.69 €$ \\
\hline
\end{tabular}


It is worth highlighting that the infraction with the greatest recurrence in 2011 consists of the lack of or insufficient supporting documentation, which results in noncompliance with article 15 of Act no. 19/2003 and punishable by fine as per article 31 .

Table 12 shows the amounts of the infringements and fines applied in 2011. The information was obtained from Judgments no. 175/2014 and no. 140/2015.

Table 12. Infraction Values and Fines Applied in 2011

\begin{tabular}{|c|c|c|c|c|c|c|}
\hline \multicolumn{2}{|c|}{ Limits } & CDS-PP & PSD & PS & BE & $\mathrm{CDU}$ \\
\hline $\begin{array}{c}\text { Infraction } \\
\text { values }\end{array}$ & - & $17,343.28 €$ & $43,117.75 €$ & $1,193,366.46 €$ & - & $171,150.69 €$ \\
\hline $\begin{array}{c}\text { Breached } \\
\text { Articles }\end{array}$ & - & 15 and 19 & 16 and 19 & 12,15 and 19 & - & 15 and 19 \\
\hline $\begin{array}{c}\text { Fines per } \\
\text { Parties }\end{array}$ & $\begin{array}{c}4,260 € \text { to } \\
85,200 €\end{array}$ & $5,500.00 €$ & $6,000.00 €$ & $6,500.00 €$ & - & $6,000.00 €$ \\
\hline Fines per & $426 €$ to & $600.00 €$ & $650.00 €$ & $700.00 €$ & - & $650.00 €$ \\
\hline $\begin{array}{c}\text { Financial } \\
\text { Agents }\end{array}$ & $34,080 €$ & & & & & \\
\hline Infractions & - & 1 & 2 & 3 & - & 3 \\
\hline
\end{tabular}

In 2011, the highest infraction value was identified in the PS accounts. However, the fine was not much different from that of the other parties. Despite the legal rule and criteria used in the TC analysis, it was found that the values of the penalties are significantly lower than the amounts of the infractions and that they remain in the campaign accounts despite the identified situations (namely contributing to the calculation of government grants received).

\section{Evolution in the period from 2005 to 2011}

Graph 1 presents the values of the infractions identified in the period under analysis. The favourable evolution in the 2011 campaign is observable, where only the PS has seen an increase in the value of infractions, although it is lower than that of other parties in previous years. The other parties significantly reduced these amounts. The BE, which had a sum of $€ 30,286$ in 2005 , was the only one with no infractions identified in the 2009 and 2011 accounts.

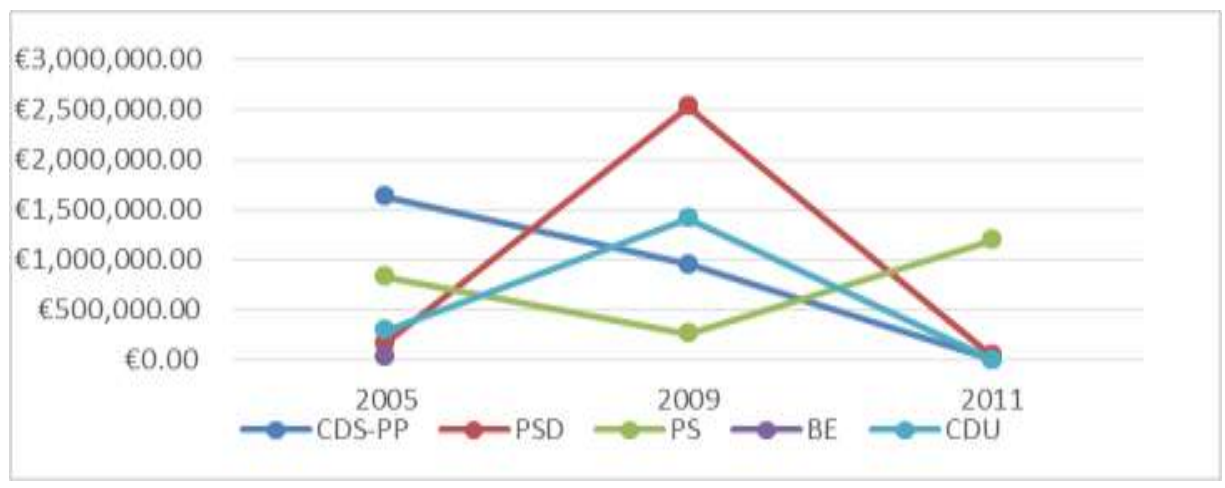

Graph 1. Infraction Values of between 2005 and 2011

Graph 2 shows the expenditure percentages in which infractions were detected in the 2005 to 2011 campaigns. The evolution is similar to that observed in the previous graph, with a significant reduction of that percentage in 2011 . 


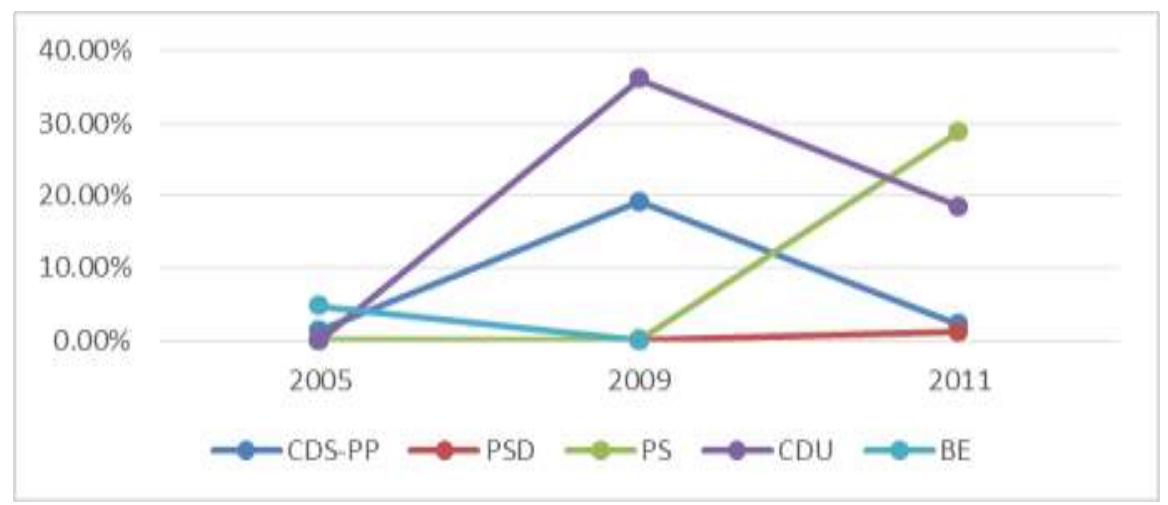

Graph 2. Percentage of expenses with infractions between 2005 and 2011

Regarding infractions in revenues, it can be seen in Graph 3 that, after a significant increase in 2009, no relevant infractions were identified in 2011.

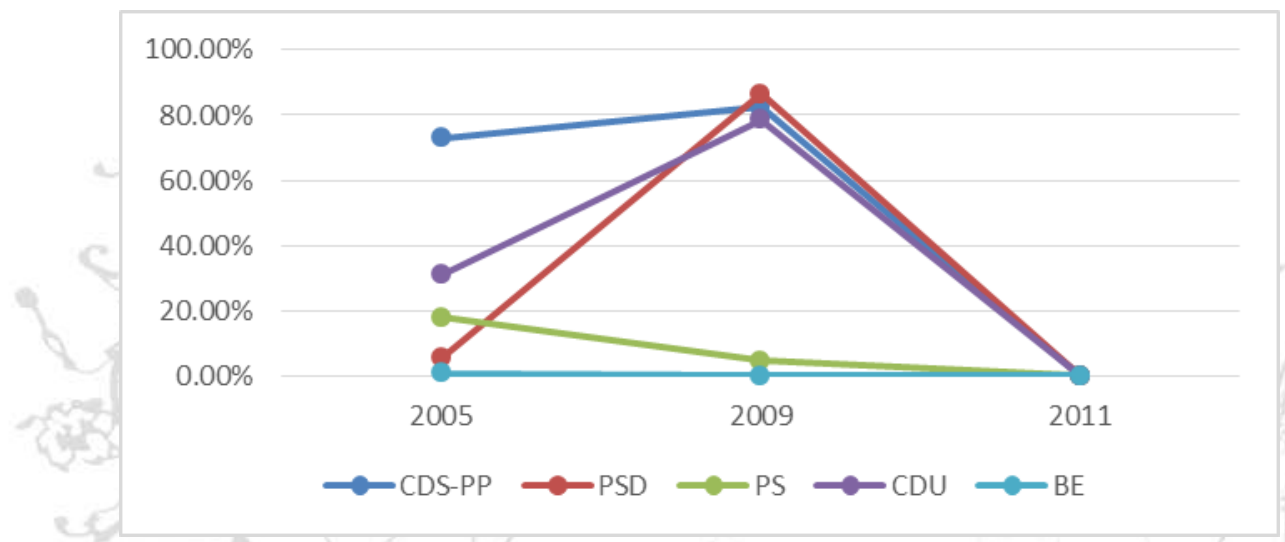

Graph 3. Percentage of revenues with infractions between 2005 and 2011

Although 2009 was the year with the highest amount of infractions, the values of fines applied peaked in 2005, as it can be seen in Graph 4.

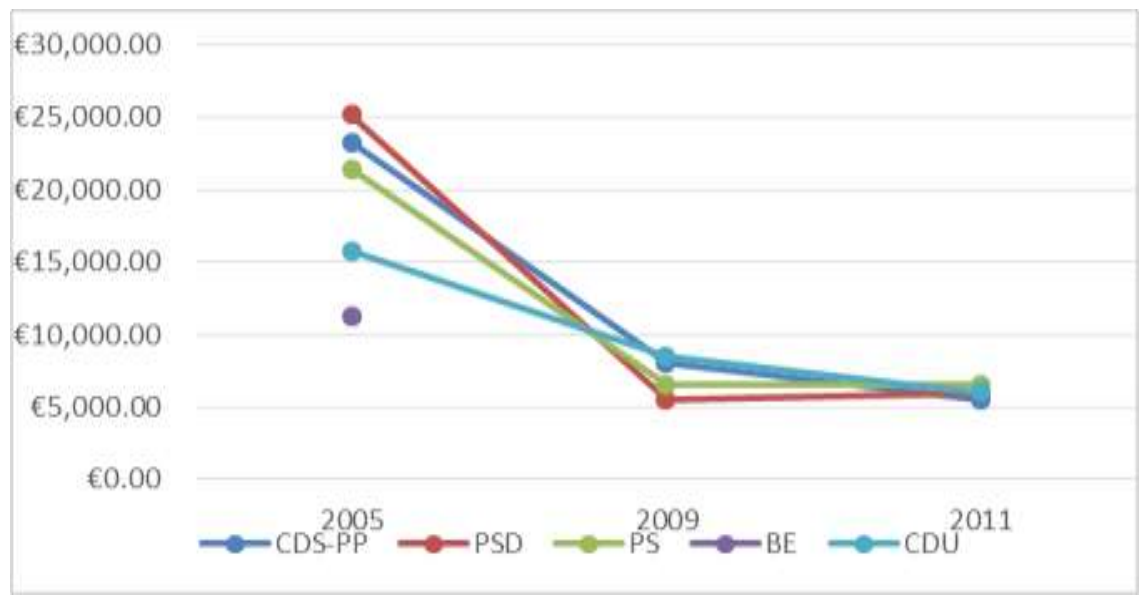

Graph 4. Fines between 2005 and 2011 


\section{Conclusions}

The electoral campaign accounts for the AR are subject to the legal framework imposed by Act no. 19/2003. This Act reviewed the rules for the financing of electoral campaigns and introduced a number of amendments aimed at greater transparency of accounts.

With the present study, our aim was to answer the following research question:

Does the portuguese legal framework applicable to electoral campaigns accounts ensure their faithful representation?

The findings of the ECFP audit reports state a common point, "unreliability" of the accounts. In fact, from the analysis of the accounts of the electoral campaigns for the Assembly of the Republic of years 2005, 2009 and 2011, there are recurrent infractions common to the various parties, such as failure to comply with the duty to detail the total revenue and expenditure of the campaign, breach of the overall obligation of accounting organisation imposed by Article 12 and applicable by Article 15, lack of or insufficient of supporting documentation, breach of the duty to pay expenses and collection of revenue through the campaign account or deposit of revenues after the elections.

It is worth mentioning that the analysis was based on the data disclosed in the TC Judgments, which may not correspond to the total amounts of the infractions identified by the Court. In all the years under review, the amounts of the fines imposed were always lower than the amounts of irregularities/illegalities and were always well below statutory limits.

It is worth highlighting that the duty to present the list of campaign actions and means is required by Organic Act no. 2/2005 and not by Act no. 19/2003. Thus, the TC does not consider this situation in the appraisal of the campaign accounts. However, the Court itself assumes that such a breach is detrimental to the control of the financing and the accounts of the campaign.

Furthermore, there is no complete equivalence between the duties imposed by Act no. 19/2003 and the applicable fines, there are duties whose noncompliance is not sanctioned with a fine. In addition, there may also be conducts which, although not corresponding to breach of the specific determinations of that Act, constitute deficiencies in or insufficient accounting organisation, which may call into question the reliability of the presented accounts.

The application of the fine does not annul or clarify the facts, which undermine the transparency of the accounts. These are considered to be provided without irregularities/illegalities being regularised. In addition, the infractions do not prevent the receipt of the grants and do not take from the accounts the revenues and/or expenses that breach the legal rules. It is worth mentioning that expenditure in which infractions are identified are considered in the total that justifies the grant to be received. Thus, it can be concluded that the benefit from irregularities/illegalities may be greater than the cost of fines, which may limit the scope of Act 19/2003. In this context, and bearing in mind the situations abovementioned, it is necessary to improve the Act in order to ensure greater reliability of electoral campaign accounts.

\section{Study Limitations}

The complete accounts of the parties' campaigns can only be consulted in person at the TC, after authorisation and appointment. In addition, unauthorised data may not be disclosed in addition to those already contained in the TC Judgments. The lack of response from the parties regarding the request for information about campaign accounts made it impossible to obtain more sources. All contacted entities, such as the parties and the Assembly of the Republic, only indicated the TC to obtain information about the subject of this study. 


\section{Future Research Proposal}

The accounts from the electoral campaigns analysed were disclosed in various accounting systems (Official Chart of Accounts and Accounting Standardisation System, general regime and micro-entities regime). As per the publication of Regulation no. 16/2013, of January 10, 2013, Regulation of the Political Financing and Accounts Entity, regarding the standardisation of procedures related to accounts from political parties and electoral campaigns, it would be interesting to study if there is a relationship between the applicable rules and the transparency of accounts.

\section{References}

Acórdão $\quad \mathrm{n}^{\mathrm{o}} \quad$ 563/2006. $\quad$ Anline]. http://www.tribunalconstitucional.pt/tc/acordaos/20060563.html. [Consult. 01 Oct. 2016].

$\begin{array}{lllll}\text { Acórdão } & \mathrm{n}^{\mathrm{o}} & \text { 417/2007. } & \text { Anline]. }\end{array}$ http://www.tribunalconstitucional.pt/tc/acordaos/20070417.html. [Consult. 01 Oct. 2016].

$\begin{array}{lllll}\text { Acórdão } & n^{\circ} & \text { [Online]. } & \text { Available at: }\end{array}$

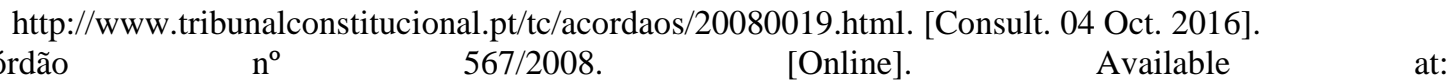

Acórdão $\quad \mathrm{n}^{\circ} \quad$ 567/2008. $\quad$ Online]. Available at: http://www.tribunalconstitucional.pt/tc/acordaos/20080567.html. [Consult. 04 Oct. 2016].
Acórdão $\quad \mathrm{n}^{\circ} \quad$ [05/2009. $\quad$ Anline]. http://www.tribunalconstitucional.pt/tc/acordaos/20090405.html. [Consult. 03 set. 2016].

Acórdão $\quad \mathrm{n}^{\mathrm{o}} \quad$ [Online]. $316 / 2010 . \quad$ Available http://www.tribunalconstitucional.pt/tc/acordaos/20100316.html. [Consult. 03 set. 2016].

Acórdão $\quad n^{\text {o }} \quad$ 77/2011. [Online]. http://www.tribunalconstitucional.pt/tc/acordaos/20110077.html. [Consult. 10 Oct. 2016].

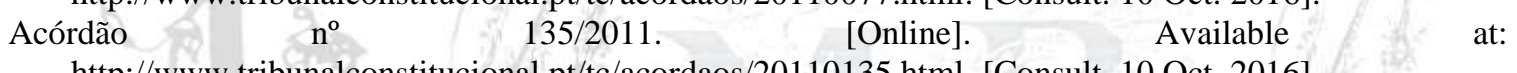
http://www.tribunalconstitucional.pt/tc/acordaos/20110135.html. [Consult. 10 Oct. 2016].

$\begin{array}{lllll}\text { Acórdão } & \mathrm{n}^{\mathbf{0}} & \text { 394/2011. } & \text { [Online]. } & \text { Available }\end{array}$ http://www.tribunalconstitucional.pt/tc/acordaos/20110394.html. [Consult. 08 Oct. 2016].

$\begin{array}{lllll}\text { Acórdão } & \mathrm{n}^{\circ} & \text { 617/2011. } & \text { [Online]. }\end{array}$ http://www.tribunalconstitucional.pt/tc/acordaos/20110617.html. [Consult. 08 Oct. 2016].

Acórdão $\quad \mathrm{n}^{\text {o }} \quad$ [Online]. $139 / 2012 . \quad$ Available at: http://www.tribunalconstitucional.pt/tc/acordaos/20120139.html. [Consult. 08 Oct. 2016].

$\begin{array}{lllll}\text { Acórdão } & \mathrm{n}^{\mathrm{o}} & \text { [Online]. } & \text { Available }\end{array}$

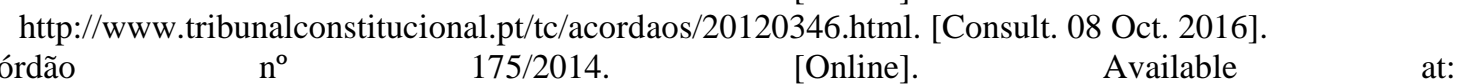

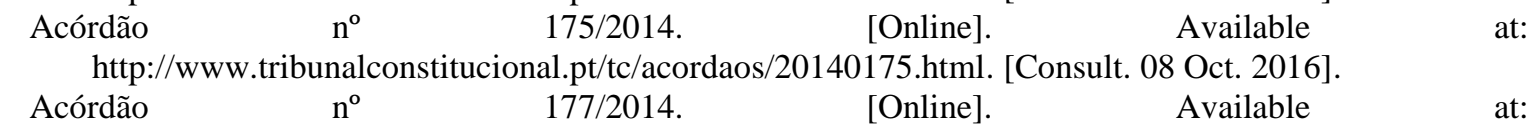
http://www.tribunalconstitucional.pt/tc/acordaos/20140177.html. [Consult. 08 Oct. 2016].

$\begin{array}{lllll}\text { Acórdão } & \mathrm{n}^{\circ} & \text { [Online]. } & \text { Available }\end{array}$ http://www.tribunalconstitucional.pt/tc/acordaos/20150140.html. [Consult. 08 Oct. 2016].

ECFP. Entidade das Contas e Financiamentos Políticos. (2011). Recomendações a Partidos Políticos e Coligações. [Online]. Available at: http://www.tribunalconstitucional.pt/tc/file/Recomendacoes-AR2011.pdf?src=1\&mid=1493\&bid=1026. [Consult. 20 fev. 2016].

Lei n. ${ }^{\circ}$ 19/2003, de 20 de junho. Lei do Financiamento dos Partidos Políticos e das campanhas eleitorais. [Online]. Available at http://www.pgdlisboa.pt/leis/lei_mostra_articulado.php?nid=1037\&tabela=leis. [Consult. 12 Aug. 2016].

Lei n. ${ }^{\circ}$ 64-A/2008, de 31 de dezembro. Orçamento do Estado para 2009. [Online]. Available at http://www.tribunalconstitucional.pt/tc/contas-legislacao030402.html. [Consult. 14 Aug. 2016].

Lei Orgânica n..$^{\circ}$ 2/2005, de 10 de janeiro. Lei de Organização e Funcionamento da Entidade das Contas e Financiamentos Políticos. [Online]. Available at: http://www.tribunalconstitucional.pt/tc/contaslegislacao030403.html. [Consult. 12 Aug. 2016]. 
Lisi, M. (2011). Os partidos políticos em Portugal: Continuidade e Transformação. Edições Almedina, SA. Coimbra.

Malem, J. (2003). Financiamento, corrupción y gobierno in Carrillo, Manuel et al, Dinero y contienda político-electoral (Mexico: Fondo de Cultura Económica/ Instituto Federal Electoral).

Miguéis, J., Luís, C., Almeida, J., Lucas, A., Rodrigues, I. \& Almeida, M. (2015). Lei Eleitoral da Assembleia da República Anotada e comentada. Lisboa: Imprensa Nacional Casa da Moeda e Comissão Nacional das Eleições. ISBN: 978-972-27-2393-0.

Peixoto, J., Baptista, L., Valente, T. (2009). Partidos políticos e Corrupção Fontes de financiamento dos partidos políticos em Portugal. Faculdade Economia da Universidade Porto. Available at www: https://www.gestaodefraude.eu/wordpress/wp-content/uploads/2009/04/Avulso004.pdf [Consult. 10 Oct. 2018].

Soares, F. (2012). O Modelo de Supervisão do Financiamento Político em Portugal. [Online]. Available at: https://repositorio.iscte-iul.pt/bitstream/10071/5881/1/Versão Final Dissertação.pdf. [Consult. 08 Oct. 2016].

Sousa, L (2005). Challenges to political financing regulation: sound external, monitoring/enforcement party accountability. Lisbon, CIES-ISCTE.

Vilela, D. (2016). Financiamento partidário: como se alteram as contas dos partidos políticos num contexto de recessão económica. Lisbon: ISCTE-IUL, 2016. Available at www: http://hdl.handle.net/10071/12472. [Consult. 10 Jan. 2017].
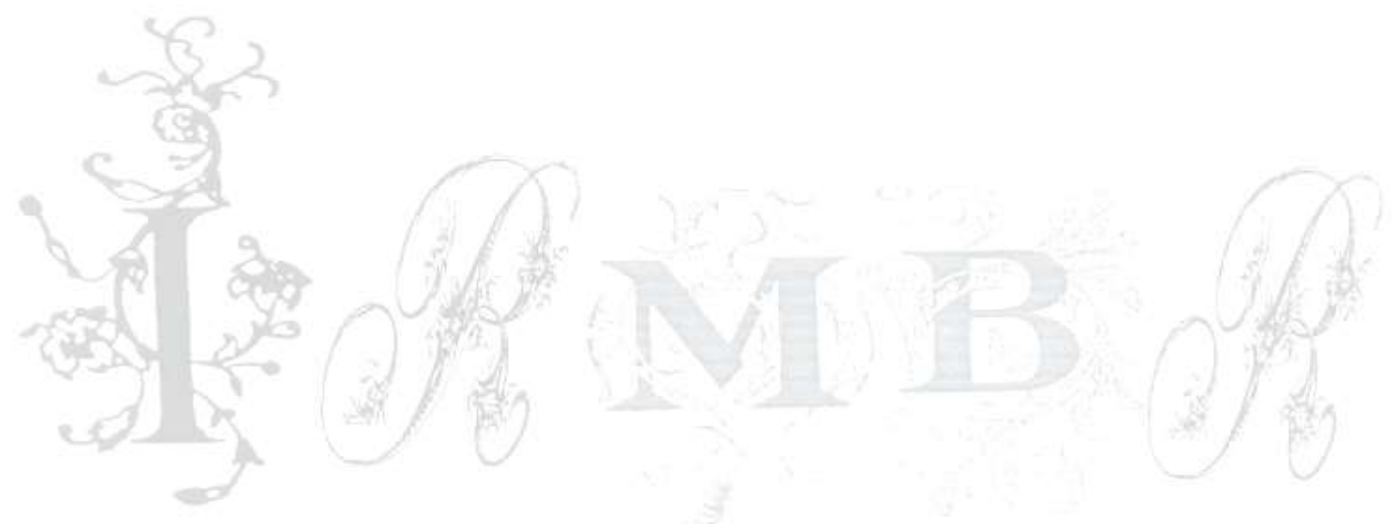